\title{
PEMETAAN ANCAMAN DAN KARAKTERISTIK KEBAKARAN HUTAN DAN LAHAN (KARHUTLA) PROVINSI LAMPUNG
}

\section{Threat Mapping and Characteristics of Forest and Land Fire in Lampung Province}

\author{
Rizki Kurnia Tohir ${ }^{1}$, Fadlan Pramatana ${ }^{2}$ \\ ${ }^{1}$ Program Studi Rekayasa Kehutanan, Institut Teknologi Sumatera, Lampung Selatan, 35365, \\ Indonesia \\ ${ }^{2}$ Program Studi Kehutanan, Universitas Nusa Cendana, Kupang, 85228, Indonesia \\ E-mail: rizki.tohir@rh.itera.ac.id, fadlan.pramatana@staf.undana.ac.id
}

Diterima: 09 Agustus 2020, Direvisi: 14 September 2020, Disetujui: 21 September 2020

DOI: 10.31849/forestra.v15i2.4705

\begin{abstract}
Lampung Province has the threat of Forest and Land Fires (FLF) based on incident reports. There is a lack of data on how the threat level of the forest and land fires, so this research is important to do. This study aims to analyze the track record and potential for FLF incidents, to analyze the characteristics and level of the FLF threat. Threat mapping is done by weighting and scoring 11 variables. These variables are divided into natural factors and human factors. The results showed that the equation that gives a weighting of $90 \%$ to natural factors. The characteristics of FLF show that natural factors are sensitive factor for the occurrence of FLF in Lampung Province. Mapping of threats shows that the area of low threat class is $244,811.96$ ha (8\%), medium threat class is $1207,716.15 \mathrm{ha} \mathrm{(40 \% )}$ and high threat class is 1,591,767.42 ha (52\%). Three districts had the highest level of threat class, namely Way Kanan, Central Lampung, and East Lampung Districts. The results of the validation of field conditions are indicated by the results of this threat mapping, so that the results of this study can be used as material for consideration by policy makers.
\end{abstract}

Keywords: Forest and land fire, Lampung Province, threat mapping

\section{ABSTRAK}

Provinsi Lampung memiliki ancaman kebakaran hutan dan lahan (Karhutla) berdasarkan laporanlaporan kejadian. Adanya kekurangan data mengenai tingkat ancaman Karhutla serta adanya sistem informasi geografi untuk menganalisis ancaman, maka penelitian ini penting untuk dilakukan. Penelitian ini bertujuan untuk menganalisis rekam jejak kejadian, menganalisis karakteristik ancaman, dan menganalisis tingkat ancaman Karhutla. Pemetaan ancaman dilakukan dengan melakukan pembobotan dan skoring pada 11 variabel. Variabel tersebut dibagi menjadi 2 faktor yaitu faktor alam dan faktor manusia. Hasil penelitian menunjukan bahwa persamaan yang memberikan bobot $90 \%$ pada faktor alam merupakan persamaan yang memiliki ketelitian yang sesuai dengan kondisi lapangan dan dapat digunakan untuk melakukan pemetaan ancaman Karhutla di Provinsi Lampung. Karakteristik Karhutla di Provinsi Lampung menunjukan bahwa faktor alam sangat sensitive untuk 
mendukung terjadinya Karhutla di Provinsi Lampung. Pemetaan ancaman menunjukan bahwa luas kelas ancaman rendah sebesar 244.811,96 ha (8\%), kelas ancaman sedang $1.207 .716,15$ ha (40\%) dan kelas ancaman tinggi seluas $1.591 .767,42$ ha (52\%). Ditemukan tiga kabupaten yang memiliki tingkat kelas keterancaman tertinggi yaitu Kabupaten Way Kanan, Lampung Tengah, dan Lampung Timur. Hasil validasi terhadap kondisi lapangan diindikasikan sesuai dengan hasil pemetaan ancaman ini, sehingga hasil penelitian ini dapat dijadikan sebagai bahan pertimbangan oleh pemangku kebijakan.

Kata kunci: Kebakaran hutan dan lahan, pemetaan ancaman, Provinsi Lampung

\section{PENDAHULUAN}

Indonesia mulai menjadi perhatian dunia internasional pada tahun 80 -an karena kasus kebakaran hutan dan lahan (Karhutla) yang tinggi. Tahun 1997-1998 kebakaran hutan dan lahan Indonesia terus terjadi mencapai 10 juta ha, dan tahun 2015 seluas 2 juta hektar terbakar dengan kerugian ekonomi sekitar 221 Triliun (Tacconi, 2003). Karhutla menimbulkan dampak negatif terhadap degradasi lahan, banjir, erosi tanah, sistem hidrologi, aktivitas sosial, dan eonomi (Harrison et al., 2006; Langner \& Siegert, 2009; Vafeidis et al., 2007).

Provinsi Lampung merupakan salah satu provinsi di Pulau Sumatera yang memiliki potensi kejadian Karhutla. Pada tahun 2014-2019 Karhutla di Provinsi Lampung mencapai 94.928,65 ha (Manggala Agni, 2019). Provinsi Lampung merupakan provinsi setiap tahun dilanda bencana Karhutla tetapi belum ada penilaian tingkat ancaman Karhutla tiaptiap daerah di seluruh Provinsi Lampung. Pencegahan Karhutla dapat dilakukan dengan menyediakan data dan informasi meliputi lokasi kebakaran dan daerah rawan kebakaran hutan dan lahan menurut PermenLH No.10/2010.

Saat ini perkembangan teknologi informasi geospasial berkembang pesat dan salah satunya dapat digunakan untuk menyediakan data dan informasi ancaman Karhutla. Tingkat ancaman kebakaran hutan dan lahan dapat dimodelkan dengan menggunakan beberapa faktor. Faktorfaktor bereferensi keruangan ini dimodelkan dengan sistem informasi geografi. Penelitian tekait penentuan tingkat kerawanan kebakaran secara spasial juga ditunjukkan oleh beberapa penelitian. Jaya et al., (2008) dan Soewarso, (2003) melakukan pemodelan kerawanan dan menemukan bahwa factor jarak dari sungai, jarak dari lahan pertanian, jarak dari jalan, 
dan jarak dari pemukiman berperan signifikan dalam tingkat kerawanan kebakaran.

Adanya teknologi pemetaan kebakaran mendukung untuk dilakukannya kajian ancaman Karhutla Provinsi Lampung. Penelitian ini bertujuan untuk menganalisis rekam jejak dan potensi kejadian Karhutla, menganalisis karakteristik ancaman Karhutla, dan menganalisis tingkat ancaman Karhutla Provinsi Lampung.

\section{METODE PENELITIAN}

Penelitian dilakukan pada seluruh wilayah administratif Provinsi Lampung. Pengolahan data dilakukan pada bulan Maret-Juli 2019. Bahan yang digunakan dalam penelitian ini adalah data titik koordinat rekam jejak kejadian Karhutla di Taman Nasional Way Kambas, data Karhutla Taman Nasional Bukit Barisan Selatan, data Karhutla dari BPBD Provinsi/ Kabupaten/ Kota, data sumber berita online, data titik hotspot dari dari Earthdata NASA (satelit VIIRS), data Citra Landsat 8 path/ row $(125 / 63,124 / 63,123 / 63,124 / 64$, dan $123 / 64$ ), peta kemiringan lereng, peta aksesibilitas Provinsi Lampung, peta jaringan sungai dan DAS Provinsi Lampung, peta penggunaan lahan.

\section{A. Analisis Variabel Penilaian Ancaman} Karhutla

\section{Analisis tipe tutupan lahan}

Klasifikasi terbimbing (supervised classification) digunakan untuk menganalisis tipe tutupan lahan. Citra Landsat 8 digunakan dengan menganalisis kanal 1 sampai 7. Uji akurasi 85\% dilakukan dengan menggunakan data titik koordinat (Liliesand \& Kiefer, 1990). Pembuatan peta bahaya kebakaran hutan dan lahan ini hanya menganalisis tutupan lahan hutan dan lahan, tutupan lahan pemukiman, jalan, dan badan air akan dikeluarkan.

\section{Analisis NDVI dan NDMI}

NDVI (Normalized Difference Vegetation Index) dihitung dari pengolahan Citra Landsat 8 pada kanal near-infrared dan red. Sedangkan NDMI (Normalized Difference Moisture Index) dihitung dari kanal near infrared dan shortwaves. Perhitungan NDVI dan NDMI menggunakan persamaan berikut (Sahu, 2014):

$$
N D V I=\frac{\text { Band } 5-\text { Band } 4}{\text { Band } 5+\text { Band } 4}
$$




$$
N D M I=\frac{\text { Band } 5-\text { Band } 6}{\text { Band } 5+\text { Band } 6}
$$

\section{Analisis suhu permukaan}

Suhu permukaan dianalisis Citra Landsat 8 band 10 dengan menggunakan formula berikut: $L \lambda=M L \times Q c a l+A L$

Keterangan: $\mathrm{L} \lambda$ (nilai radian spektral (Watts/(m2* $\left.\operatorname{srad}^{*} \mu \mathrm{m}\right)$ ); $\quad$ ML (faktor pengkali spesifik); Qcal (nilai digital citra spesifik); AL (faktor penambah spesifik).

$$
T=\frac{\mathrm{K} 2}{\ln \left(\frac{K 1}{L \lambda}\right)+1}
$$

Keterangan: T (suhu (Kelvin)); K1 (konstanta (774.89)); K2 (Konstanta (1 321.08))

\section{Analisis kemiringan lereng (slope)}

Peta kelerengan dibuat dari data SRTM (Shutlle Radar Tophography Mission). Data dan diberi kelas-kelas. Kelerengan yang semakin curam akan berpotensi lebih besar untuk terbakar dikarenakan adanya faktor arah rambat api.

5. Analisis jarak dari aksesibilitas dan pusat aktivitas masyarakat

Peta jarak dari aksesibilitas dan pusat aktivitas masyarakat (jalan, pemukiman, perkebunan, ladang, sawah, dan sungai) dibuat dengan metode eculidean distance.

\section{B. Analisis Keruangan dan Atribut}

Setelah seluruh data masing-masing variable (11 variabel) dianalisis dan menghasilkan peta tematik, selanjutnya dianalisis menggunakan teknik skoring dan pengkelasan. Adapun skor 11 variabel terjadi pada (Tabel 1). Skor yang diberikan menunjukan pengaruh tiap karakteritik dari suatu variabel terhadap bahaya Karhutla.

Peta tematik hasil overlay kemudian dianalisis atributnya untuk melihat tingkat ancaman kebakaran. Penilaian dilakukan menggunakan dua formula pembobotan berdasarkan penelitian (Amalina et al., 2016). Penilaian didasarkan atas informasi bahwa penyebab Karhutla lebih banyak disebabkan oleh aktivitas manusia dibandingkan terjadi secara alami (Adinugroho et al., 2005; Page et al., 2002). Kedua formula yang diujikan digunakan untuk melihat kesensitifan kajian, apakah faktor alam sangat mendukung bencana Karhutla dan atau melihat apakah faktor manusia sangat sensitif terhadap kejadian Karhutla. Formula yang digunakan sebagai berikut:

$\mathbf{Y}=0.1(\mathrm{X} 1+\mathrm{X} 2+\mathrm{X} 3+\mathrm{X} 4+\mathrm{X} 5)+0.9$

$(\mathrm{X} 6+\mathrm{X} 7+\mathrm{X} 8+\mathrm{X} 9+\mathrm{X} 10+\mathrm{X} 11)$ 
$\mathbf{Y}=0.9(\mathrm{X} 1+\mathrm{X} 2+\mathrm{X} 3+\mathrm{X} 4+\mathrm{X} 5)+0.1$

$(\mathrm{X} 6+\mathrm{X} 7+\mathrm{X} 8+\mathrm{X} 9+\mathrm{X} 10+\mathrm{X} 11)$

Keterangan: Arti simbol terdapat pada (Tabel 1).

Persamaan 1 memiliki bobot 0.9 pada

faktor manusia dan bobot 0.1 pada faktor alam. Berbanding terbalik dengan persamaan 2. Hasil pemodelan ancaman Karhutla masing-masing formula dievaluasi dengan menggunakan data titik kejadian Karhutla dan hotspot.

Tabel 1 Variabel dan skor penelitian

\begin{tabular}{|c|c|c|c|c|}
\hline Variabel dan Data & Karakteristik & Skor & Tingkat Ancaman & Sumber \\
\hline Tutupan lahan (X1) & Savana/ alang-alang (kering) & 5 & Sangat bahaya & \multirow{6}{*}{ (Erten et al., 2004) } \\
\hline \multirow[t]{5}{*}{ Data: Citra Landsat 8} & Hutan (sedikit kering) & 4 & Bahaya & \\
\hline & Hutan rawa (lembab) & 3 & Sedang & \\
\hline & Hutan bakau (lembab) & 3 & Sedang & \\
\hline & Rawa (sedikit basah) & 2 & Tidak bahaya & \\
\hline & Badan air (basah) & 1 & sangat tidak bahaya & \\
\hline NDVI (X2) & NDVI $<0.35$ & 5 & Sangat bahaya & \multirow{5}{*}{ (Pramatana, 2016) } \\
\hline \multirow[t]{4}{*}{ Data: Citra Landsat 8} & $0.36 \leq \mathrm{NDVI}<0.43$ & 4 & Bahaya & \\
\hline & $0.43 \leq \mathrm{NDVI}<0.5$ & 3 & Sedang & \\
\hline & $0.5 \leq \mathrm{NDVI}<0.57$ & 2 & Tidak bahaya & \\
\hline & NDVI $>=0,57$ & 1 & Sangat tidak bahaya & \\
\hline NDMI (X3) & $\mathrm{NDMI} \leq 0.25$ & 5 & Sangat bahaya & \multirow{5}{*}{ (Pramatana, 2016) } \\
\hline \multirow[t]{4}{*}{ Data: Citra Landsat 8} & $0.25 \leq \mathrm{NDMI}<0.30$ & 4 & Bahaya & \\
\hline & $0.30 \leq \mathrm{NDMI}<0.35$ & 3 & Sedang & \\
\hline & $0.35 \leq \mathrm{NDMI}<0.40$ & 2 & Tidak bahaya & \\
\hline & $\mathrm{NDMI}>=0.40$ & 1 & Sangat tidak bahaya & \\
\hline \multirow{5}{*}{$\begin{array}{l}\text { Kemiringan lereng } \\
(\text { slope })(\mathrm{X} 4)\end{array}$} & $>35 \%$ & 5 & Sangat bahaya & \multirow{5}{*}{ (Erten et al., 2004) } \\
\hline & $35-25 \%$ & 4 & Bahaya & \\
\hline & $25-10 \%$ & 3 & Sedang & \\
\hline & $10-5 \%$ & 2 & Tidak bahaya & \\
\hline & $>5 \%$ & 1 & Sangat tidak bahaya & \\
\hline Suhu permukaan (X5) & Suhu $>35^{\circ} \mathrm{C}$ & 5 & Sangat bahaya & \multirow{5}{*}{ (Jaiswal et al., 2002) } \\
\hline \multirow[t]{4}{*}{ Data: Citra landsat 8} & $30<$ suhu $\leq 35^{\circ} \mathrm{C}$ & 4 & Bahaya & \\
\hline & $25<$ suhu $\leq 30^{\circ} \mathrm{C}$ & 3 & Sedang & \\
\hline & $20<$ suhu $\leq 25 \mathrm{C}$ & 2 & Tidak bahaya & \\
\hline & suhu $\leq 20^{\circ} \mathrm{C}$ & 1 & sangat tidak bahaya & \\
\hline \multirow[t]{5}{*}{ Jarak dari jalan (X6) } & Jarak $\leq 100 \mathrm{~m}$ & 5 & Sangat bahaya & \multirow{5}{*}{ (Jaiswal et al., 2002) } \\
\hline & $100 \mathrm{~m}<\mathrm{jarak} \leq 200 \mathrm{~m}$ & 4 & Bahaya & \\
\hline & $200 \mathrm{~m}<\mathrm{jarak} \leq 300 \mathrm{~m}$ & 3 & Sedang & \\
\hline & $300 \mathrm{~m}<\mathrm{jarak} \leq 400 \mathrm{~m}$ & 2 & Tidak bahaya & \\
\hline & Jarak $>400 \mathrm{~m}$ & 1 & sangat tidak bahaya & \\
\hline \multirow[t]{5}{*}{ Jarak dari sungai $(\mathrm{X} 7)$} & Jarak $\leq 100 \mathrm{~m}$ & 5 & Sangat bahaya & \multirow{5}{*}{ (Jaiswal et al., 2002) } \\
\hline & $100 \mathrm{~m}<\mathrm{jarak} \leq 200 \mathrm{~m}$ & 4 & Bahaya & \\
\hline & $200 \mathrm{~m}<\mathrm{jarak} \leq 300 \mathrm{~m}$ & 3 & Sedang & \\
\hline & $300 \mathrm{~m}<\mathrm{jarak} \leq 400 \mathrm{~m}$ & 2 & Tidak bahaya & \\
\hline & Jarak $>400 \mathrm{~m}$ & 1 & sangat tidak bahaya & \\
\hline \multirow[t]{5}{*}{ Jarak dari ladang (X8) } & Jarak $\leq 1000 \mathrm{~m}$ & 5 & Sangat bahaya & \multirow{5}{*}{ (Erten et al., 2004) } \\
\hline & $1000 \mathrm{~m}<\mathrm{jarak} \leq 2000 \mathrm{~m}$ & 4 & Bahaya & \\
\hline & $2000 \mathrm{~m}<\mathrm{jarak} \leq 3000 \mathrm{~m}$ & 3 & Sedang & \\
\hline & $3000 \mathrm{~m}<\mathrm{jarak} \leq 4000 \mathrm{~m}$ & 2 & Tidak bahaya & \\
\hline & Jarak $>4000 \mathrm{~m}$ & 1 & sangat tidak bahaya & \\
\hline
\end{tabular}




\begin{tabular}{|c|c|c|c|c|}
\hline Variabel dan Data & Karakteristik & Skor & Tingkat Ancaman & Sumber \\
\hline \multirow{5}{*}{$\begin{array}{l}\text { Jarak dari perkebunan } \\
\text { (X9) }\end{array}$} & Jarak $\leq 1000 \mathrm{~m}$ & 5 & Sangat bahaya & \multirow{5}{*}{ (Erten et al., 2004) } \\
\hline & $1000 \mathrm{~m}<\mathrm{jarak} \leq 2000 \mathrm{~m}$ & 4 & Bahaya & \\
\hline & $2000 \mathrm{~m}<\mathrm{jarak} \leq 3000 \mathrm{~m}$ & 3 & Sedang & \\
\hline & $3000 \mathrm{~m}<\mathrm{jarak} \leq 4000 \mathrm{~m}$ & 2 & Tidak bahaya & \\
\hline & Jarak $>4000 \mathrm{~m}$ & 1 & sangat tidak bahaya & \\
\hline \multirow{5}{*}{$\begin{array}{l}\text { Jarak dari sawah } \\
\text { (X10) }\end{array}$} & Jarak $\leq 1000 \mathrm{~m}$ & 5 & Sangat bahaya & \multirow{5}{*}{ (Erten et al., 2004} \\
\hline & $1000 \mathrm{~m}<\mathrm{jarak} \leq 2000 \mathrm{~m}$ & 4 & Bahaya & \\
\hline & $2000 \mathrm{~m}<$ jarak $\leq 3000 \mathrm{~m}$ & 3 & Sedang & \\
\hline & $3000 \mathrm{~m}<$ jarak $\leq 4000 \mathrm{~m}$ & 2 & Tidak bahaya & \\
\hline & Jarak $>4000 \mathrm{~m}$ & 1 & sangat tidak bahaya & \\
\hline \multirow{5}{*}{$\begin{array}{l}\text { Jarak dari } \\
\text { permukiman }(\mathrm{X} 11)\end{array}$} & Jarak $\leq 1000 \mathrm{~m}$ & 5 & Sangat bahaya & \multirow{5}{*}{ (Erten et al., 2004) } \\
\hline & $1000 \mathrm{~m}<\mathrm{jarak} \leq 2000 \mathrm{~m}$ & 4 & Bahaya & \\
\hline & $2000 \mathrm{~m}<$ jarak $\leq 3000 \mathrm{~m}$ & 3 & Sedang & \\
\hline & $3000 \mathrm{~m}<\mathrm{jarak} \leq 4000 \mathrm{~m}$ & 2 & Tidak bahaya & \\
\hline & Jarak $>4000 \mathrm{~m}$ & 1 & sangat tidak bahaya & \\
\hline
\end{tabular}

Formula untuk menilai ancaman yang dipakai adalah formula dengan hasil yang menunjukan bahwa titik rekam kejadian Karhutla berada pada tingkat ancaman yang tinggi. Skor ancaman

kebakaran dibagi dengan menggunakan nilai tengah dan standar deviasi menjadi tiga kelas tingkat ancaman yaitu tinggi, sedang, dan rendah (Tabel 2).

Tabel 2. Penentuan kelas bahaya

\begin{tabular}{cc}
\hline Skor Y & Tingkat ancaman \\
\hline$y \min \leq y<(\bar{Y}-1 / 2 S D)$ & Rendah \\
$(\bar{Y}-1 / 2 S D)$ & \\
$\leq y<$ & Sedang \\
$(\bar{Y}+1 / 2 S D)$ & \\
$y \geq(\bar{Y}+1 / 2 S D)$ & Tinggi \\
\hline
\end{tabular}

\section{HASIL DAN PEMBAHASAN}

\section{A. Rekam Jejak Karhutla Provinsi}

\section{Lampung}

Hasil rekam jejak kejadian Karhutla di Provinsi Lampung oleh Badan Penanggulangan Bencana Daerah (BPBD) Provinsi, Kabupaten dan Kota tahun 20112019 telah terjadi 220 kasus (34 kasus kebakaran Hutan dan 186 kebakaran lahan (Tabel 3). $90 \%$ kasus yang terjadi disebabkan oleh ulah manusia. Jumlah kebakaran terbanyak terjadi di Kota Bandar lampung berjumlah 117 kali yang seluruhnya terjadi pada lahan (semak belukar/ alang-alang) sempit milik masyarakat, disusul tulang bawang dan pringsewu. 
Tabel 3 Rekap Rekam Kejadian Karhutla Per Kabupaten Di Provinsi Lampung*

\begin{tabular}{|c|c|c|c|c|c|c|c|c|c|c|}
\hline \multirow{2}{*}{ Kabupaten/ Kota } & \multicolumn{9}{|c|}{ Tahun } & \multirow{2}{*}{ Jumlah } \\
\hline & 2011 & 2012 & 2013 & 2014 & 2015 & 2016 & 2017 & 2018 & 2019 & \\
\hline Kota Bandar Lampung & 52 & 29 & - & - & 33 & 1 & - & 1 & 1 & 117 \\
\hline Tulang Bawang & - & 5 & - & 7 & 20 & 1 & - & - & - & 33 \\
\hline Pringsewu & - & 1 & - & - & 14 & - & - & - & - & 15 \\
\hline Mesuji & 6 & - & - & - & 1 & - & - & - & 3 & 10 \\
\hline Lampung Utara & 6 & 3 & - & - & - & - & - & - & - & 9 \\
\hline Lampung Barat & - & - & - & - & 7 & - & 1 & - & 2 & 10 \\
\hline Way Kanan & - & - & - & - & 2 & - & 1 & - & 2 & 5 \\
\hline Lampung Timur & - & - & - & - & - & - & - & - & 5 & 5 \\
\hline Pesawaran & - & - & - & - & 2 & - & - & - & 1 & 3 \\
\hline Lampung Tengah & - & - & - & - & - & - & - & 1 & 2 & 3 \\
\hline Lampung Selatan & - & 1 & - & - & - & - & - & - & 2 & 3 \\
\hline Tanggamus & - & - & - & - & 3 & - & - & - & - & 3 \\
\hline Tulang Bawang Barat & - & - & - & - & 2 & - & - & - & - & 2 \\
\hline Pesisir Barat & - & - & - & - & 1 & - & - & - & 1 & 2 \\
\hline Kota Metro & - & - & - & - & - & - & - & - & - & $\mathbf{0}$ \\
\hline Jumlah & 64 & 39 & $\mathbf{0}$ & 7 & 85 & 2 & 2 & 1 & 19 & 220 \\
\hline
\end{tabular}

*Sumber Data Primer BPBD Kota/Kabupaten dan Sumber Sekunder Berita

Data rekam kejadian diatas memiliki bias yang tinggi karena masih adanya data yang tidak terekap oleh masing-masing instansi. Sehingga kedepannya perlu adanya koordinasi antar instansi, sehingga memiliki data yang akurat mengenai rekam kejadian Karhutla.

Berdasarkan statistik Direktorat Jenderal Pengendalian Perubahan Iklim (PPI) tahun 2019, rekap hotspot (titik panas) di Lampung dari tahun 2013-2018 berfluktuasi (Gambar 1). Tahun 2014-2015 merupakan tahun terbanyak titik panas, karena pada tahun 2015 Indonesia mengalami cuaca ekstrem El-Nino, kemudian menurun hingga tahun 2016 dan pada tahun 2017 kecenderungan jumlah titik panas meningkat kembali hingga tahun 2018. 


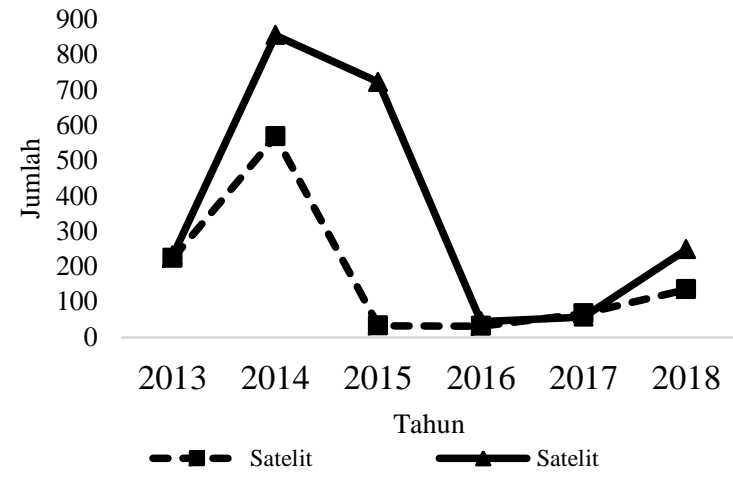

Gambar 1 Sebaran Hotspot di Provinsi Lampung Tahun 2013-2018 (Ditjen PPI 2018)

Hasil rekap hotspot Ditjen PPI berdasarkan status lahan 2018 (Gambar 2) menunjukan bahwa Non Hutan (APL/ Areal Penggunaan Lain) memiliki jumlah titik panas tertinggi baik bersumber dari data TERRA/AQUA (LAPAN) maupun NOAA (ASMC). Hal ini sesuai dengan data rekam kejadian karutla BPBD Provinsi dan BPBD Kabupaten/Kota tahun 2011-2019 tercatat jumlah kebakaran non hutan (APL) 169 kejadian, sedangkan hutan sebanyak 20 kejadian.

Hutan konservasi menempati peringkat kedua jenis kawasan yang memiliki jumlah hotspot tertinggi. Di Provinsi Lampung terdapat hutan konservasi yaitu Taman Nasional Way Kambas dan Taman Nasional Bukit Barisan Selatan yang memiliki rekam kejadian kebakaran hutan. Berdasarkan penelitian
Amalina et al., (2016) menyebutkan bahwa pada rentang tahun 2011-2014 telah terjadi 522 kejadian kebakaran di Taman Nasional Way Kambas dan dominan terjadi pada tutupan savana. Hasil penelusuran data di Taman Nasional Bukit Barisan Selatan pada bulan Agustus-September 2015 pernah terjadi sebanyak 12 kali kejadian dikarenakan cuaca ekstrim El-Nino dan pembakaran secara sengaja oleh manusia.

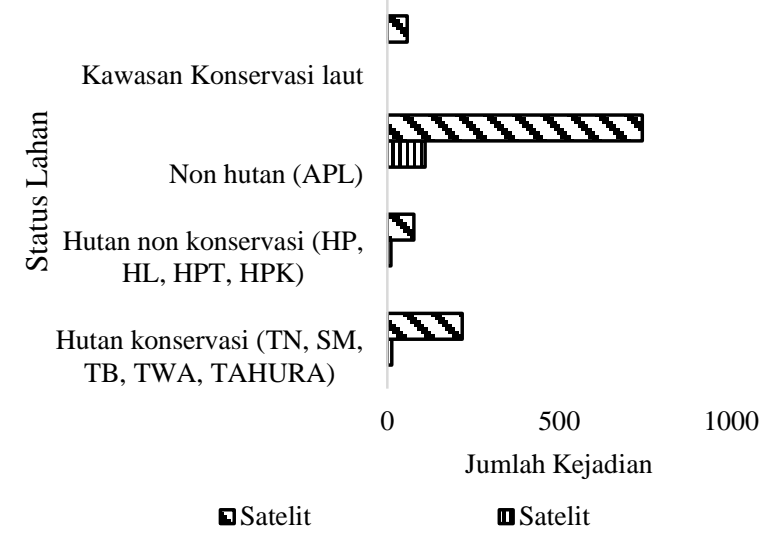

Gambar 2 Sebaran Hotspot berdasarkan status Lahan di Provinsi Lampung tahun 2018

\section{B. Karakteristik Ancaman Karhutla Provinsi Lampung}

Karakteristik kebakaran hutan dan lahan (Karhutla) di Provinsi Lampung berdasarkan data rekam kejadian menunjukan bahwa kebakaran lahan (lahan terbuka) memiliki intensitas kejadian cukup tertinggi dan disebabkan karena ulah 
manusia. Hal ini sesuai dengan penelitian (Amalina et al., 2016) yang menemukan bahwa kejadian Karhutla di Taman Nasional Way Kambas dominan terjadi pada tutupan lahan savana (lahan terbuka) dan disebabkan oleh manusia.

Hasil pemetaan ancaman Karhutla Provinsi Lampung divalidasi menggunakan titik panas (hotspot) dan rekam jejak kejadian Karhutla di lapangan sebanyak 2572 titik. Hasil pemetaan ancaman Karhutla menggunakan persamaan 1 yang memberikan bobot $90 \%$ faktor manusia dan $10 \%$ faktor alam (Gambar 3) menunjukan hasil bahwa kelas ancaman rendah 940.631,38 ha, ancaman sedang 1.195.380,07 ha, dan ancaman tinggi 908.284,08 ha.

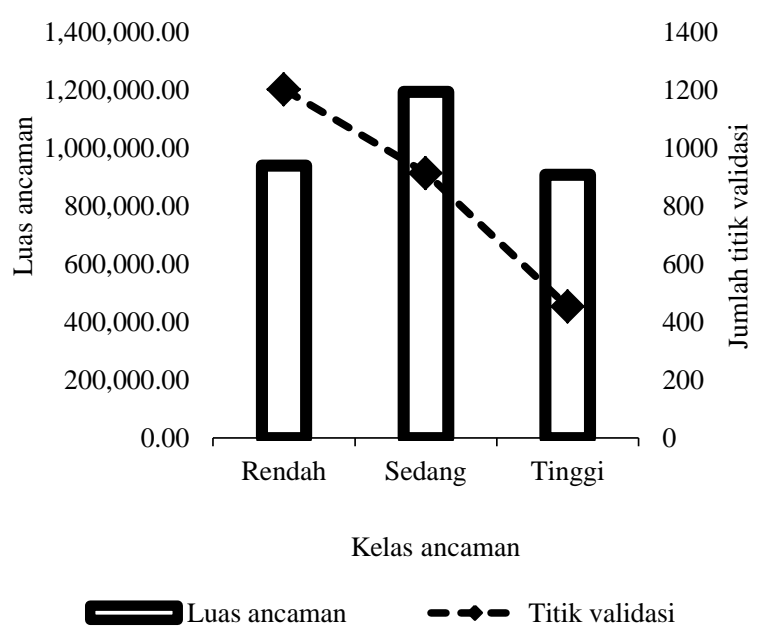

Gambar 3 Luas ancaman dan validasi titik kebakaran pada setiap kelas ancaman
Karhutla menggunakan persamaan 1 (faktor dominansi manusia)

Hasil pemetaan ancaman menggunakan persamaan 1 menunjukan bahwa kelas ancaman Karhutla tertinggi pada kelas ancaman sedang. Hasil validasi titik kebakaran terhadap kelas ancaman Karhutla persamaan 1 menunjukan bahwa titik kebakaran tertinggi berada pada kelas ancaman rendah sebanyak 1203 titik kejadian. Hasil ini menyimpulkan bahwa pemetaan ancaman kebakaran hutan dan lahan di Provinsi Lampung dengan menggunakan persamaan 1 (faktor dominansi manusia) tidak bisa digunakan sebagai dasar formula penentuan ancaman kebakaran di Provinsi Lampung karena kurang teliti dan tidak sensitive terhadap fakta kondisi lapangan.

Hasil pemetaan ancaman Karhutla menggunakan persamaan 2 yang memberikan bobot $90 \%$ faktor alam dan $10 \%$ faktor manusia (Gambar 4) menunjukan hasil bahwa kelas ancaman rendah 244.811,96 ha, ancaman sedang 1.207.716,15 ha, dan ancaman tinggi $1.591 .767,42$ ha. 


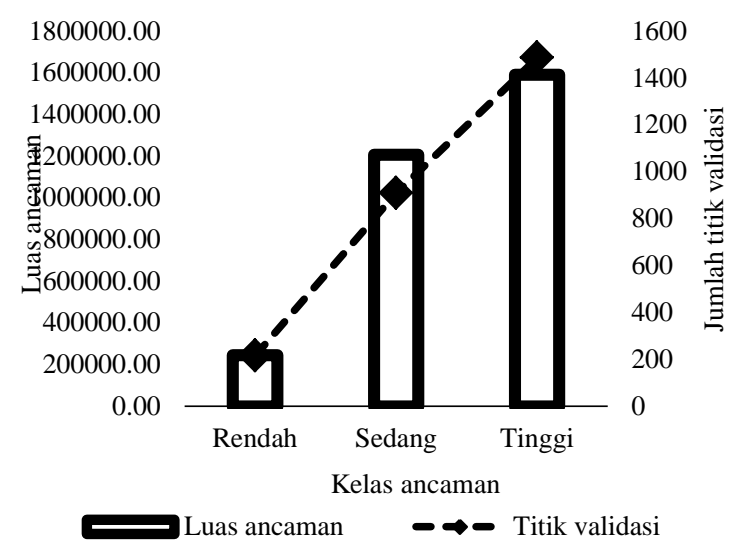

Gambar 4. Luas ancaman dan validasi titik kebakaran pada setiap kelas ancaman Karhutla

Hasil pemetaan ancaman menggunakan persamaan 2 ini menunjukan bahwa kelas ancaman tinggi merupakan kelas yang memiliki luasan paling tinggi juga. Hasil validasi sebaran titik hotspot dan titik rekam kejadian menunjukan bahwa titik validasi paling banyak tersebar pada kelas ancaman tinggi sebanyak 1487 titik validasi. Oleh karena itu karakteristik Karhutla di Provinsi Lampung menunjukan bahwa faktor alam merupakan faktor paling tinggi pendukung terjadinya Karhutla di Provinsi Lampung. Hal tersebut menunjukkan kondisi alam Provinsi Lampung sangat mendukung terjadinya Karhutla baik dari sisi bahan bakar, kemiringan lereng dan suhu. Sehingga pengaruh aktivitas manusia terhadap alam (hutan dan lahan) di Provinsi Lampung bisa menyebabkan terjadinya kebakaran hutan.

\section{Ancaman Karhutla Provinsi Lampung}

Hasil uji sensitivitas titik rekam kejadian Karhutla di Provinsi Lampung dengan pemetaan ancaman menunjukan bahwa persamaan 2 (90\% factor alam dan $10 \%$ factor manusia) merupakan formula yang bisa diterima untuk menentukan dan memetakan ancaman Karhutla Provinsi Lampung. Hasil pemetaan didapatkan tingkat ancaman Karhutla Provinsi Lampung yang tersaji pada (Gambar 5). Analisis luas masing-masing kelas ancaman kebakaran hutan dan lahan di Provinsi Lampung yaitu kelas ancaman rendah seluas 244.811,96 Ha (8\%), kelas ancaman sedang 1.207.716,15 ha (40\%) dan kelas ancaman tinggi seluas 1.591.767,42 ha $(52 \%)$.

Hasil pemetaan menunjukan bahwa lampung memiliki tingkat ancaman kebakaran yang tinggi, diindikasikan karena Provinsi Lampung memiliki tutupan lahan dan hutan yang tinggi, disertai dengan suhu yang relatif tinggi. Hal ini didukung oleh BNPB Pusat yang menyatakan bahwa Provinsi Lampung merupakan salah satu 
provinsi yang memiliki karakteristik hutan

dan lahan yang mudah terbakar ketika

musim kering (Wardah, 2019).

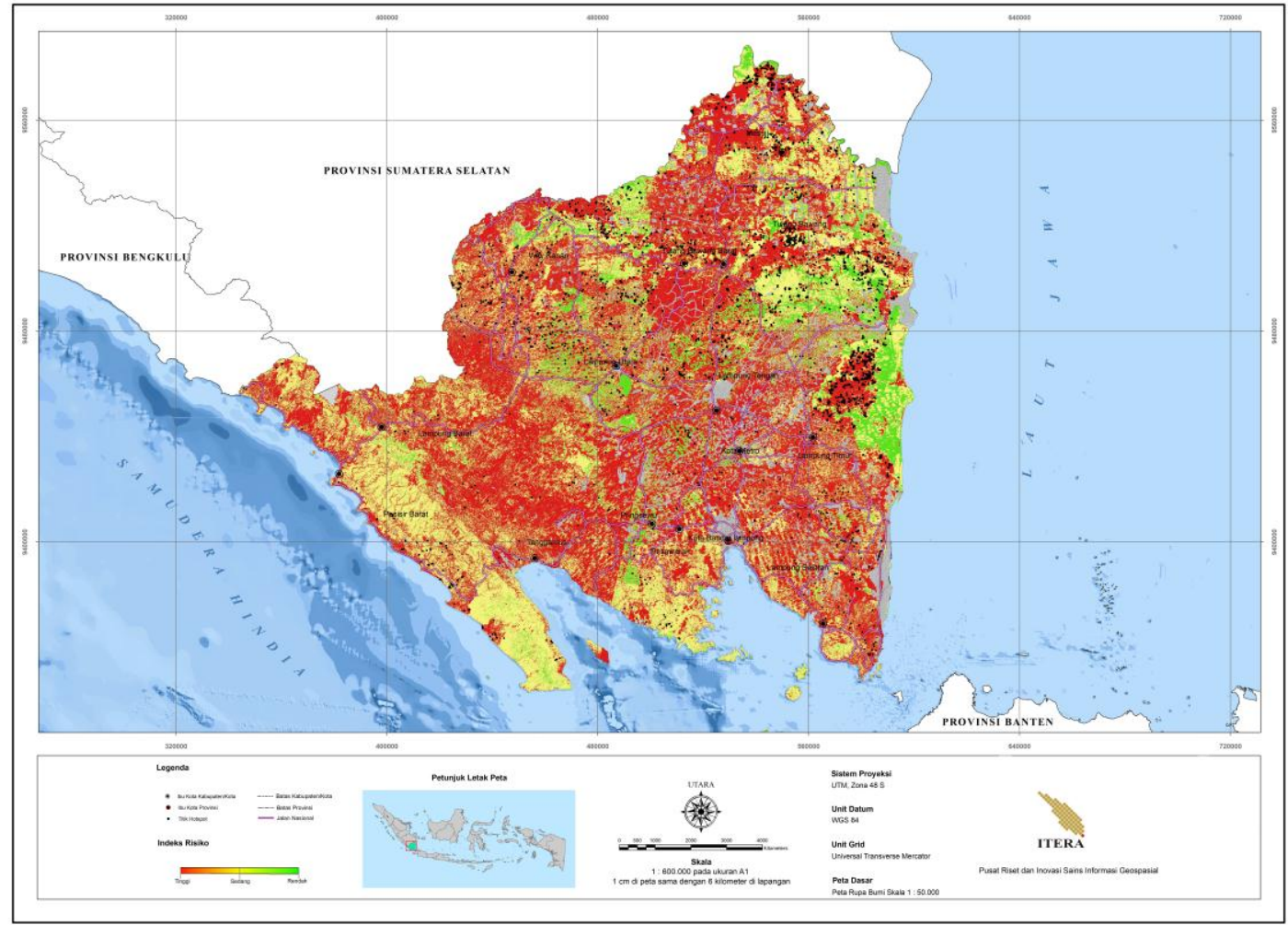

Gambar 5. Peta ancaman kebakaran hutan dan lahan Provinsi Lampung

Hasil analisis ancaman Karhutla per kabupaten ditemukan tiga kabupaten berdasarkan luas areal kawasan hutan dan lahan yang memiliki tingkat kelas keterancaman tertinggi yaitu Kabupaten Way Kanan, Lampung Tengah, dan Lampung Timur (Tabel 4). Kabupaten Way
Kanan berdasarkan peta dasar tutupan lahan KLHK memiliki hutan dan lahan seluas $345.522,90$ ha.

Kabupaten Way Kanan merupakan kabupaten yang memiliki luas hutan dan lahan yang termasuk kedalam ancaman tinggi paling luas yaitu dengan komposisi 
ancaman rendah seluas 20.085,94 ha $(5,80 \%)$, sedang $130.449,70$ ha $(37.65 \%)$ dan tinggi $195.987,26$ ha $(56,56 \%)$. Way kanan memiliki kawasan yang rentan dan pernah terjadi kebakaran seperti perkebunan karet PTPN VII Unit Usaha Blambangan
Umpu, kebun tebu PT Pemuka Sakti Manis (PSM), perkebunan kelapa sawit masyarakat, dan daerah hutan Gunung Katun Kecamatan Baradatu (Sandi, 2019) dan data BPBD 2015 tahun 2015).

Tabel 4 Kelas Ancaman Kebakaran Hutan dan Lahan Provinsi Lampung Per Kabupaten

\begin{tabular}{clrrr}
\hline \multirow{2}{*}{ No. Kabupaten } & & \multicolumn{2}{c}{ Kelas Ancaman (Ha) } & Tendah \\
Sedang & \multicolumn{1}{c}{ Tinggi } \\
\hline 1 & Way Kanan & 20085,94 & 130449,70 & 195987,26 \\
2 & Lampung Tengah & 62453,85 & 128475,04 & 195628,18 \\
3 & Lampung Timur & 46693,70 & 112680,61 & 174103,77 \\
4 & Tanggamus & 3175,46 & 110924,82 & 166446,19 \\
5 & Tulang Bawang & 27001,13 & 104927,35 & 132699,68 \\
6 & Lampung Barat & 7138,92 & 80912,64 & 117212,22 \\
7 & Lampung Selatan & 5757,86 & 71342,67 & 116489,89 \\
8 & Lampung Utara & 37617,09 & 84735,01 & 115698,47 \\
9 & Mesuji & 12001,01 & 86461,97 & 103898,77 \\
10 & Pesisir Barat & 5959,88 & 194201,01 & 96275,77 \\
11 & Tulang Bawang Barat & 4452,13 & 25459,22 & 83665,23 \\
12 & Pesawaran & 2551,62 & 57503,53 & 58286,38 \\
13 & Pringsewu & 8943,14 & 14384,97 & 30171,31 \\
14 & Metro & 799,06 & 980,47 & 2616,38 \\
15 & Bandarlampung & 181,16 & 4277,15 & 2587,93 \\
\hline
\end{tabular}

Kabupaten Lampung Tengah merupakan kabupaten kedua yang memiliki kawasan hutan dan lahan yang termasuk kedalam kelas ancaman tinggi terluas. Kecamatan Bandar Mataram dan Kecamatan Terusan Nunyai merupakan dua kecamatan yang termasuk kedalam lima lokasi yang memiliki ancaman kebakaran tinggi di lampung per tanggal 5 Agustus 2019 (Putra, 2019). Beberapa kecamatan yang rentan terhadap Karhutla di Kabupaten Lamteng karena memiliki areal kawasan perkebunan. Kebun tebu yang terletak di Kecamatan Gunung Sugih pada 21 Agustus 2018 terbakar (Hardanto, 2018). Kebun Tebu lainnya yang terbakar pada 11 Agustus 2019 terjadi di Kecamatan Terbanggi Besar (Islam, 2019). Dua kecamatan di Kabupaten Lampung Timur memiliki kawasan perkebunan sawit milik PTPN VII yaitu kebun sawit Unit Usaha Padang Ratu di Kecamatan Padang Ratu dan kebun sawit Unit Usaha Bekri di Kecamatan Bekri. Kecamatan Trimujo 
sering kali masyarakat membakar lahan jagung pasca panen (Aini, 2019).

Dominansi kawasan yang terbakar di Kabupaten Lampung Tengah adalah lahan perkebunan.

Kabupaten Lampung Timur (Lamtim) memiliki luas kelas ancaman tinggi sebesar $52,21 \%$ dari total luas hutan dan lahan Kabupaten Lamtim. Kecamatan Labuhan Maringgai merupakan kecamatan yang memiliki kawasan hutan dan lahan dengan kelas ancaman tinggi terluas yaitu $40.817,19$ ha. Kecamatan ini memiliki ancaman tertinggi karena memiliki kawasan Taman Nasional Way Kambas (TNWK) yang merupakan areal konservasi hutan yang biasanya terjadi bencana kebakaran. Rekam kejadian hutan TNWK telah terjadi dari tahun 2011-2015 sebanyak 522 kali kebakaran hutan (Amalina et al., 2016). Selain itu dari Januari-Agustus 2019 TNWK telah mengalami kebakaran hutan dengan total luas kebakaran 625 ha padang alang-alang (Agus). Hasil analisis peta ancaman Karhutla di Provinsi Lampung dengan data rekam jejak kejadian Karhutla pada masing-masing daerah dapat terkonfirmasi. Oleh karena itu penilaian ancaman yang dilakukan dalam penelitian ini dapat diterima.

\section{KESIMPULAN DAN SARAN}

\section{A. Kesimpulan}

Hasil analisis rekam jejak kejadian Karhutla di Provinsi Lampung pada tahun 2011-2019 oleh BPBD Provinsi tercatat mencapai 220 kasus. Hasil rekapitulasi Hotspot Ditjen PPI pada tahun 2010-2018 menggunakan satelit NOAA (ASMC) 2719 titik dan satelit TERRA/AQUA 2163 titik.

Persamaan yang memberikan bobot 90\% pada factor alam merupakan persamaan yang memiliki ketelitian yang sesuai dengan kondisi lapangan dan digunakan untuk melakukan pemetaan ancaman Karhutla di Provinsi Lampung.

Karakteristik Karhutla di Provinsi Lampung menunjukan bahwa faktor alam merupakan faktor paling tinggi pendukung terjadinya Karhutla. Hal tersebut menunjukkan kondisi alam Provinsi Lampung sangat mendukung terjadinya Karhutla.

Kelas ancaman Karhutla di Provinsi Lampung yaitu kelas ancaman rendah sebesar $244.811,96$ ha $(8 \%)$, kelas ancaman sedang $1.207 .716,15$ ha $(40 \%)$ dan kelas 
ancaman tinggi seluas $1.591 .767,42$ ha (52\%). Ditemukan tiga kabupaten berdasarkan luas areal kawasan hutan dan lahan yang memiliki tingkat kelas keterancaman tertinggi yaitu Kabupaten Way Kanan, Lampung Tengah, dan Lampung Timur.

\section{B. Saran}

Diperlukan kerjasama antar pihak untuk melakukan monitoring pencegahan Karhutla di Provinsi Lampung. Selain itu data kejadian Karhutla di kelola dengan lebih baik karena akan lebih memudahkan untuk menentukan arah kebijakan penangulangan Karhutla di daerahnya

\section{UCAPAN TERIMA KASIH}

Penelitian ini terwujud atas kerjasama

Balai Penanggulangan Bencana Daerah Provinsi Lampung dan Pusat Riset dan Inovasi Sains Informasi Geospasial Institut Teknologi Sumatera.

\section{DAFTAR PUSTAKA}

Adinugroho, W. C., Suryadiputra, I. N. N., Saharjo, B. H., \& Siboro, L. (2005). Panduan Pengendalian Kebakaran Hutan dan Lahan Gambut. Proyek Climate Change, Forests and Peatlands in Indonesia. Wetlands International -
Indonesia Programme dan Wildlife Habitat Canada.

Aini, N. (2019). Petani Lampung Bakar Ladang Sisa Tanaman Jagung. https://nasional.republika.co.id/berita/p veei7382/petani-lampung-bakarladang-sisa-tanaman-jagung

Amalina, P., Prasetyo, L. B., \& Rushayati, S. B. (2016). Forest Fire Vulnerability Mapping in Way Kambas National Park. Procedia Environmental Sciences, 33, 239-252. https://doi.org/10.1016/j.proenv.2016. 03.075

Erten, E., Kurgum, V., \& Musaoglu, N. (2004). Forest fire risk zone mapping and GIS: A Case Study. http://www.isprs.org/proceedings/XX XV/congress/yf/papers/927.pdf.

Hardanto, D. T. (2018). Kebun Tebu di Gunung Sugih Terbakar, Warga Terobos Kobaran Api. https://lampung.tribunnews.com/2018/ 08/23/kebun-tebu-di-gunung-sugihterbakar-warga-terobos-kobaran-api

Harrison, M. E., Cheyne, S. M., Sulistiyanto, Y., \& Rieley, J. O. (2006). Biological Effects of Smoke From Dry-Season Fires in Non-Burnt Areas of the Sabangau Peat Swamp Forest , Central Kalimantan , Indonesia. Wildlife Conservation, April 2016, 2-6. 
Islam, A. (2019). Kakek padamkan api cucu tewas terbakar di kebun tebu. https://radarlampung.co.id/2019/08/12/ kakek-padamkan-api-cucu-tewasterbakar-di-kebun-tebu/

Jaiswal, R. K., Mukherjee, S., Raju, K. D., \& Saxena, R. (2002). Forest fire risk zone mapping from satellite imagery and GIS. International Journal of Applied Earth Observation and Geoinformation, 4(1), 1-10. https://doi.org/10.1016/S03032434(02)00006-5

Jaya, I. N. S., Boer, R., Samsuri, \& Faturakhman. (2008). Forest Fire Vulnerability in Central Kalimantan.

Langner, A., \& Siegert, F. (2009). Spatiotemporal fire occurrence in Borneo over a period of 10 years. Global Change Biology, 15(1), 48-62. https://doi.org/10.1111/j.13652486.2008.01828.x

Liliesand, T. M., \& Kiefer, R. W. (1990). Penginderaan jauh dan interpretasi citra. Gadjah Mada University Press.

ManggalaAgni. (2019). Rekapitulasi Luas Kebakaran Hutan dan Lahan (ha) Per Provinsi di Tahun 2014-2019. http://sipongi.menlhk.go.id/hotspot/lua s_kebakaran

Page, S. E., Siegert, F., Rieley, J. O., Boehm, H. D. V., Jaya, A., \& Limin,
S. (2002). The amount of carbon released from peat and forest fires in Indonesia during 1997. Nature, 420(6911), 61-65. https://doi.org/10.1038/nature01131

Pramatana, F. (2016). Tingkat Keterancaman Habitat Jalak Bali (Leucopsar rothchildi) melalui pendekatan pemetaan bahaya kebakaran di Taman Nasional Bali Barat. Institut Pertanian Bogor.

Putra, M. A. (2019). Waspada! Beberapa Wilayah di Lampung Rawan Kebakaran.

https://kumparan.com/lampunggeh/wa spada-beberapa-wilayah-di-lampungrawan-kebakaran-1rcAbTVGogJ

Sahu, A. (2014). Identification and mapping of the water-logged areas in Purba Medinipur part of Keleghai river basin, India: RS and GIS methods. International Journal of Advanced Geosciences, 2(2). https://doi.org/10.14419/ijag.v2i2.245 2

Sandi. (2019). Akibat Puntung Rokok, 30 Hektar Lahan Perkebunan Karet PTPN VII Way Kanan Terbakar. https://www.kupastuntas.co/2019/08/1 8/akibat-puntung-rokok-30-hektarlahan-perkebunan-karet-ptpn-vii-waykanan-terbakar/

Soewarso. (2003). Penyusunan Pencegahan 
Kebakaran Hutan Rawa Gambut dengan Menggunakan Model Prediksi. Institut Pertanian Bogor.

Tacconi, L. (2003). Kebakaran hutan di Indonesia: penyebab, biaya dan implikasi kebijakan. In Kebakaran hutan di Indonesia: penyebab, biaya dan implikasi kebijakan (Vol. 38, Issue 38). Center for International Forestry Research_. https://doi.org/10.17528/cifor/001200

Vafeidis, A. T., Drake, N. A., \& Wainwright, J. (2007). A proposed method for modelling the hydrologic response of catchments to burning with the use of remote sensing and GIS. Catena, 70(3), 396-409. https://doi.org/10.1016/j.catena.2006.1 1.008

Wardah, F. (2019). BNPB: 6 Provinsi Darurat Kebakaran Hutan dan Lahan. https://www.voaindonesia.com/a/bnpb -6-provinsi-darurat-kebakaran-hutandan-lahan/5024342.html 